\title{
Transformation of Managerial Competencies within the Context of Global Challenges
}

\author{
Viktoriya Bondarenko ${ }^{1, *}$, Olesia Diugowanets ${ }^{1},{\text { Oksana } \text { Kurei }^{1}}^{1}$ \\ ${ }^{1}$ Uzhhorod National University, Faculty of History and International Relations, Narodna Square 3, 88000 Uzhhorod, Ukraine
}

\begin{abstract}
This contribution presents an analysis of the transformational changes in the global environment on the content of modern models of managerial competencies. Theoretical approaches to the definition of managerial competencies according to international standards are studied, and on this basis a hierarchy of competencies, within the context of their acquisition through professional training, is determined. The predictions and changes in the basic competencies of managers in the near future (2025) are analysed. Sets of general managerial (organizational) competencies (hard skills) and non-specialized supra-professional competencies (soft skills) are defined and compared. Digital competences and intercultural competences are defined as conceptually new skills required by a modern effective manager.
\end{abstract}

Keywords: management; competence; model; hard skills; soft skills

\section{Introduction}

The process of the high-quality professional training of future managers within the context of the latest global challenges, including COVID-19, requires a thorough rethink of the competency model of a successful manager. The transformation of the global environment has affected various areas of business and requires urgent critical analysis and the search for additional supra-professional skills for modern leaders, providing them with self-development, cognitive thinking, the ability to adapt to market turbulence and digitalization.

A systematic analysis of scientific papers reveals the defocus and one-sidedness of the research into the topic of this study. This includes analyses of the theoretical models of a successful manager [1,2], predictions about future managerial skills [3-5], consideration of the impact on businesses and management structures of the post COVID-19 era, the requirements being placed on managers in the era of intellectual development under Industry 4.0 [6-8], and the determination and attempted definition of the essence of digital literacy and digitalization of the global economy [9-11].

In our opinion, digital and intercultural competencies are conceptually new managerial skills that are required to overcome the above challenges due to global economic developments. The digital competencies of managers should be considered from at least three vantage points: the ability to perceive new technologies; the ability to utilise them at work; and the ability to transfer these technologies when training staff and stakeholders. Acquiring the competence of cultural self-awareness is a fundamental skill that helps prevent cultural conflicts and helps managers to understand the impact of their own cultural beliefs (personal self-awareness) and values on stakeholders, taking into account management practices in different cultures.

However, despite the large number of scientific papers, and given the recent challenges of globalization, the system of competencies of a modern successful manager has yet to be generalized; there are no definitions of the new supra professional skills managers should acquire and possess and which should be incorporated into managerial training programmes. The purpose of this study is therefore to clarify and define the competencies of a successful manager, thereby setting clear priorities for the training of a competitive manager in the face of recent global challenges.

\section{Methodology}

For the purpose of the research, the main stages of the study were set as follows: 1) systematic and structural analysis of the theoretical approaches for determining the competencies of managers according to international standards, and determination of the hierarchy of managerial competencies required within the context of their acquisition during training; 2) analysis of predictions and changes in basic managerial competencies in the near future (2025) to determine the priorities for the professional training of competitive managers; 3) analysis of "post COVID-19" analytical reviews by

\footnotetext{
* Corresponding author: viktoriya.bondarenko@gmail.com
} 
top international consultancy firms and other organizations to identify new managerial competencies and determine the content thereof.

For each of these stages, the following research methods were used: system analysis method (competency models were considered as a complex system of interrelated skills that together ensure the success of a leader in practice); abstractand-logical analysis (the formation of hypotheses, conclusions based on evidence, confirmation of the author's opinions by other authors, analytical and empirical research results, which reduce the probable level of subjectivity of the research results); and the abstraction method (i.e. distraction from additional related information in order to determine the top key competencies of a manager in the "post COVID-19" era). In addition to this systematic approach, general scientific approaches were also used: chronological (while studying the changes in the skills of a successful manager over time, from the initial class models to predictive models); and terminological (while clarifying the essence of digital competencies and cultural identity).

The information basis of the study consisted of scientific papers, theoretical models of managerial competencies, empirical research, analytical reviews and predictions by international organizations and companies. To obtain objective and reliable results from the scientific research and to confirm the hypotheses, the following criteria were used to select the source base: representativeness, time, and the level of generalization of information based on empirical data.

\section{Results and Discussion}

Ukraine's integration into the global economy has led to a wide range of changes that have complicated management problems, intensified competition, and paved the way for an innovative breakthrough in Ukraine's economy. Ensuring the requirements for its successful transition requires the high-quality training of (future) managers who are able to think critically, strategically, and are able to implement a modern management philosophy. This includes:

- $\quad$ providing the conditions for the self-realization of an individual's creative potential;

- developing the link between fundamental knowledge and highly professional practical skills and abilities;

- the adaptation of staff to the environment with constantly changing responsibilities;

- the reorientation of employees' values and strengthening the role of work ethics;

- $\quad$ effective problem solving related to global competition and the informatization of innovations [12];

- the ability to properly perform duties under the constant pressure of political, social, economic and psychological disincentives (stress, pressure, uncertainty in society and in specific groups);

- $\quad$ increasing the role of the manager and deepening the communication with staff, as well as competence in the implementation of management tasks (contributes to a significant improvement in the mental health of all employees) [13];

- $\quad$ providing behavioural, affective and cognitive dimensions to interpersonal communications [14];

- $\quad$ increasing interest in self-education, a high level of self-discipline;

- the constant strengthening of the business reputation of managers, which requires managerial success, extensive experience and deep knowledge of their field of activity, high moral qualities, knowledge of foreign languages, etc.

The competencies approach as a personnel management tool gives a clear definition of the professional and behavioural requirements for an employee depending on their managerial level, profession, position and tasks. In both Ukrainian and foreign approaches, there is a distinction between the concepts of "competency" and "competence". The main difference between them is as follows: competency is a concept that defines the field of professional activity in which a person is competent, it is a description of work related tasks or expected results; competence is a concept that highlights aspects of human behaviour associated with the performance of work and defines the main characteristics of the individual who has achieved or is able to achieve good results within the activity [15].

Competency models are a key tool in human resource management systems and practices. Over the past 30 years, public administration systems around the world have undergone major reforms, and competency management has already been implemented in the public sector in some OECD countries [16].

The manager's competency model is a complete set of competencies and indicators of the behaviour necessary for the successful performance of functional responsibilities by an employee [17].

Recent research on managerial competency models suggests the use of generalized blocks of managerial behaviour, which together form a corporate model of their competencies (corporate competencies of the manager). In this regard, three options are used for building models of managerial competencies:

1) universal competency models of the most successful companies; 
2) universal models of competencies adjusted in accordance with organizational goals and corporate cultural values;

3) building a competency model from scratch based on the development strategy, mission and corporate culture of an organization with the help of external consultants or independently [18].

Universal (standardized, basic) models of competencies have been published in scientific literature [5, 19-24]. Furthermore, a characteristic trend for models of organizational competencies is both the use by companies of only general competencies and the development of managerial competencies for managers of different levels or special competencies for employees of key departments.

To identify essential skills, existing models of managerial competencies were analysed, thereby applying the method of systematization for the formation of a comprehensive modern model of competencies within the context of global challenges (see Table 1).

Table 1. System analysis of competency models

(according to international standards; basic skills without consideration for the challenges of the global environment)

\begin{tabular}{|c|c|}
\hline Competency model & Highlighted competencies \\
\hline \multirow[t]{2}{*}{$\begin{array}{l}\text { SHL's "Eight } \\
\text { Competencies" model } \\
\text { (international management } \\
\text { standards - specialist, } \\
\text { manager, team leader) }\end{array}$} & $\begin{array}{l}\text { - entrepreneurial qualities (business, creativity, determination, strategy) } \\
\text { - qualities of the executive (leadership, planning and organization, quality orientation, } \\
\text { persuasiveness) } \\
\text { - professional qualities (special knowledge, analysis and problem solving, oral and written } \\
\text { communication) } \\
\text { - personal qualities (interpersonal understanding, flexibility, stability, personal motivation) }\end{array}$ \\
\hline & $\begin{array}{l}\text { SHL consultants use the method of direct attributes based on cards with universal competencies } \\
\text { models for certain categories of staff: UCF model (Universal Competency Framework), IMC model } \\
\text { (Inventory of Management Competencies), CC model (Customer Contact), WSC model (Work Styles } \\
\text { Competency), PMC model (Perspectives on Management Competencies), DDA model (Director's } \\
\text { Development Audit) }\end{array}$ \\
\hline $\begin{array}{l}\text { "20 Facets" model } \\
\text { (areas of the manager`s } \\
\text { activity through } \\
\text { competencies) }\end{array}$ & management skills; motivation; decision-making skills; individual traits; interpersonal skills \\
\hline $\begin{array}{l}\text { Whiddett \& Hoolyforde } \\
\text { model } \\
\text { (a competency model } \\
\text { development based on } \\
\text { company resources) }\end{array}$ & $\begin{array}{l}\text { - business development (personal development, ideas generation and justification) } \\
\text { - achievement of results (planning, management clarity, goal setting) } \\
\text { - analysis - work with information (analysis and decision making) } \\
\text { - people (teamwork, influence, relationship management) }\end{array}$ \\
\hline $\begin{array}{l}\text { SHRM model } \\
\text { (Society for Human } \\
\text { Resource Management) }\end{array}$ & $\begin{array}{l}\text { business knowledge; personal capacity; strategic contribution; practical experience; possession of } \\
\text { management technologies }\end{array}$ \\
\hline $\begin{array}{l}\text { CFT model } \\
\text { (Corporate Financial } \\
\text { Technologies) }\end{array}$ & $\begin{array}{l}\text { system thinking; result orientation; analytical skills; creativity; flexibility; quick and adequate } \\
\text { response; ability to learn; organizational skills; delegation of powers; ability to time-plan; ability to } \\
\text { listen to others, maintain feedback; presentation and negotiation skills; ability to retransmit } \\
\text { knowledge and skills }\end{array}$ \\
\hline
\end{tabular}

Source: Authors.

An analysis of the standardized models in Table 1 shows that most approaches consist of 4-12 competencies, which are often focused on ensuring the financial success of a company and team building, which are implemented through leadership, organizational skills and communication. Therefore, a general model of managerial competencies should include: (1) hard skills; and (2) soft skills [25].

Hard skills are necessary for the successful achievement of business goals. They are mandatory for management and, until recently, occupied key positions in managerial competency models. Management competencies include, for example, strategic vision, generation of effective decisions, task formulation and the planning of their implementation stages, organization of implementation processes, management of subordinates, professional external and internal communication skills, and achieving results.

Soft skills are important both in professional activities and in everyday life. Soft skills allow managers to be successful regardless of the specifics of their activities and the direction of their work. Traditionally, the following types of nonspecialized supra-professional competencies are distinguished:

- communicative competencies (ability to listen, persuade, argue, conduct presentations and negotiations, networking, self-presentation, public speaking, business correspondence);

- $\quad$ self-management competencies (management of emotions, time, self-development, stress, planning and goal setting, feedback use, focus on services); 
- cognitive competencies (creative and critical thinking, cognitive flexibility, structural and logical thinking, decision making, tactical and strategic thinking, information retrieval and analysis, project thinking).

The higher the professional level of the manager, the greater the role soft skills play. As a result, general professional competencies take a back seat.

Hard skills apply to a specific group of positions. As a rule, they do not play a key role for administrative management because the higher the professional level of the manager, the more subordinates and employees can advise him on various professional issues. It should be noted that managerial competencies do not become irrelevant [5]. On the contrary, their role is still important. However, having non-specialized supra-professional competencies, especially of the cognitive type, will allow administrative and crisis management to apply their hard skills more effectively.

The modern world of business is changing rapidly, so it is important to pay attention not only to the competence of employees, but also to predict the competencies that will guarantee success in the future [4]. According to a World Economic Forum study, the competencies needed to perform most work will change significantly by 2022, especially for managers at all levels of government. It is expected that the average global "skills stability" - the share of core competencies that will remain unchanged - will be about 58\%. Competencies such as technological design, which emphasizes the growing demand for various forms of technological competence, will be in demand. However, along with knowledge of the latest technologies, personal competencies (creativity, originality and initiative, critical thinking, persuasion and negotiation) will play a significant role [26].

According to the previously referenced global prediction of managerial competency models for $2015-2020,35 \%$ of key required competencies have already changed [27]. In 2020, instead of managerial competencies, non-specialized supra-professional competencies of the cognitive type have come to the fore. Changes in the list of priorities are the result of understanding current trends in the business environment. It has become clear that in 2020, competitive advantage and leadership will come to those companies with cognitive competencies, namely thinking skills and creativity, because it is on these abilities that an organization depends to effectively adapt to change. Consequently, these competencies have become a priority in development programmes for modern management (Tab. 2).

Table 2. Changes in key competencies in 2020 and predictions for 2025

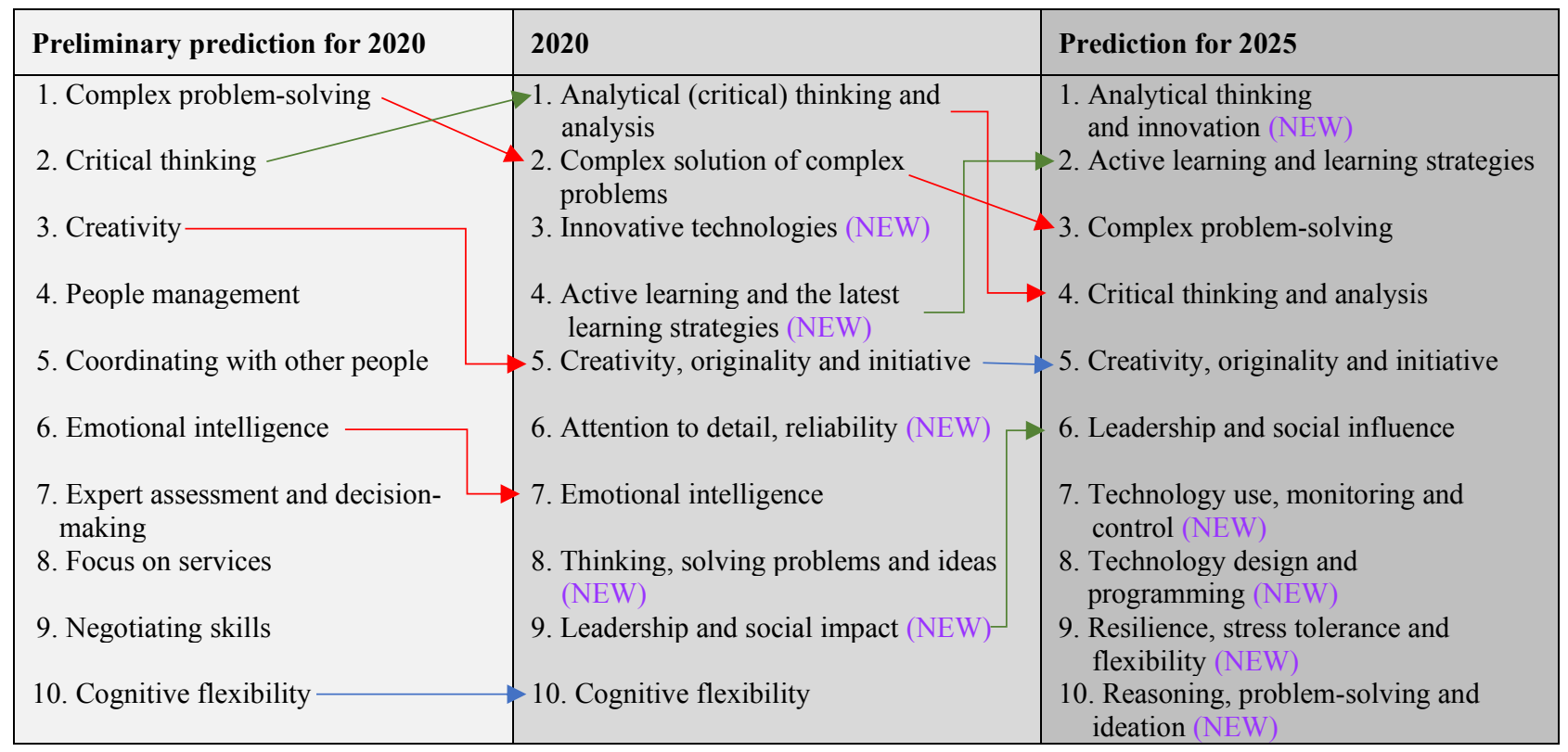

Source: Authors.

The World Economic Forum 2020 data shows changes in the most popular competencies of future employees over the next 5 years [26]. The pandemic-related global recession of 2020 and the shift towards the expected introduction of new technologies, automation and further innovations by 2025 will form the core competencies or even skill groups of future managers. These include analytical thinking and innovation, integrated problem-solving, prudence, as well as selfmanagement skills, such as active learning, resilience, flexibility, creativity, originality and initiative (see Table 2).

In the midst of the pandemic recession, and given the shift to distance working, online learning and training with digital tools will increase, thereby presenting a window of opportunity for the (re)training of future managers, with new educational technology tools and the use of both formal and informal methods of acquiring professional skills.

As is evident in Table 2, critical thinking, as predicted, tops the rankings for the most important competency in both 2020 and 2025. Since the 1990s, critical thinking and the appropriate training skills have become extremely relevant. This was due to the urgent need for managers to make informed decisions on various aspects of company management, as well as the ability to perceive and analyse the information received. Complicated business processes require non-standard 
solutions. As a result, creativity, originality and initiative are now becoming key competencies of management and companies. These competencies not only enable adaptation to change, but also actively shape new industries and markets.

Importantly, emotional intelligence and cognitive flexibility have become new to core competencies in 2020. Cognitive flexibility is the mental ability to switch from one thought to another, as well as to think about several things at once [28]. From the standpoint of administrative management, cognitive flexibility can be a person's ability to adapt thinking in the transition from an old situation to a new one, as well as the ability to overcome habitual reactions and thoughts in new conditions. Moreover, cognitive flexibility involves the simultaneous consideration of many aspects of the phenomenon, such as two parameters of an object or many aspects of a complex situation. In an open, large, and highly versatile world, this ability becomes extremely important. With its help, managers are able to apply their creativity and solve complex problems.

It is the shared opinion of the authors that it is advisable to emphasize and develop the emotional competencies of a manager in connection with the growing role of emotional intelligence, i.e. the ability to use one's own behaviour and mood to influence the work of subordinates. Under the emotional competencies of a manager is understood: the ability to adequately tolerate a stressful situation without getting into a state of stress; the ability to make independent decisions regardless of external instructions or orders; the ability to defend their own point of view without violating the rights and interests of subordinates; the ability to solve problems of a professional and personal nature, taking into account the current situation in the company; the ability to consciously empathize with the experience of the interlocutor, given their state of mind; the ability to control impulsivity, i.e. actions without sufficient conscious control, being influenced by circumstances or emotions; and the ability to soberly assess reality regardless of the circumstances [3].

These theoretical and consistent predictions of a successful manager's skills have been significantly influenced by the COVID 19 pandemic, which on a global scale can be described in one term as a "reset" of the business and global economic system as a whole.

A report from the Accenture consulting company [8] on the impact of the coronavirus pandemic shows that viable business strategies should provide flexible methods of managing employees, creating digital jobs; differentiation and stable supply chains for customers; stable IT infrastructure and systems; digital channels and e-commerce platforms. In other words, industrial enterprises need to scale their digital innovations across production and all their ecosystems [8].

The McKinsey global consultancy brand, in its analytics within the context of COVID-19, and in particular in its article "Digital strategy in a time of crisis", notes that every company should: review the strategies of digital transformation; form anti-crisis headquarters (or "nerve centres"), which should quickly review the portfolio of value proposals and offer new solutions; and build new business models where the most vulnerable or responsible elements look different. In practical terms, this refers to supply chains, data security, remote control modes, manpower, and of course, larger-scale automation.

Within this context, McKinsey discusses behavioural change in terms of the courage it takes to propose change and quickly revisit old skills and paradigms, as well as in terms of the need to learn quickly, experiment and test hypotheses and new solutions, simplify and focus at the same time and constantly [6].

The case of the British company KHC emphasizes that today we are not considering the transition to digital technology, but already thinking about how to do it faster and scale it up throughout a company. Prior to doing so, KHC invested heavily in digital platforms, which provided the necessary flexibility and efficiency in response to COVID-19 [7]. The company's management emphasizes: "Today you need zero tolerance for previously established systems or approaches, and you must constantly ask yourself new, important questions about the future. Be ruthless. Choose a technology partner who is willing to invest in technology just like you." [7].

In summarizing the analytical reports, it becomes clear that enterprises of all activities are becoming more digital and are being reorganized into new flexible structures. Digital transformation or Industry 4.0 in the post-Covid-19 era significantly change the essence of business activities. Company managements are being forced into taking this into account, and managers must possess digital competencies. Since, in fact, such competencies are new components in the model of a successful leader, there are differences in their understanding. Some [11] argue that these competencies are closely linked to leadership skills that drive change. Digital leadership is revealed in two ways: digital competencies / literacy and strong leadership skills that drive a company's digital transformation. The study hypothesizes that digital leadership is the foundation of a manager's psychological well-being [11].

According to a survey conducted by the British Computer Association, only 52\% of employers believe that their employees have digital literacy skills, $42 \%$ of students at one Italian university do not know about the dangers of free Wi$\mathrm{Fi}$, and $50 \%$ of students download files without checking their content and source [10].

Summing up, it can be concluded that the digital competencies of a manager include: a technological dimension: through which managers are able to explore and solve technical problems in a new way; a cognitive dimension: the ability to read, analyse, select and interpret information on the basis of relevance, reliability and suitability; a social dimension: the ability to teach and upskill employees in digital literacy, constructively and responsibly, and the ability to be a leadermotivator and generator of change and innovation based on digital technologies. 
Analytical reviews on the impact of the coronavirus pandemic also touch on issues of corporate, team and community culture as key foundations for the adaptation to change. In addition, a critical analysis of different research papers has identified the new competencies of successful managers of global companies, such as intercultural competencies, cultural identity, intercultural communication, global thinking, and more.

International business experts agree that in order to succeed in global business, managers need flexibility and an appropriate attitude to practices and values that can be radically different from those to which they are accustomed. Being a modern manager with global intercultural competencies is not only where they manage people, but also how they do it. [9].

As globalization intensifies, managers are confronted with an environment that is becoming more complex, dynamic, uncertain, and highly competitive than ever before. The starting point for overcoming these challenges is to acquire the competence of cultural self-awareness - an understanding of the impact of one's own cultural conditioning, assessment of one's own cultural beliefs, values, and a deep understanding of how companies and management practices differ in different cultures [29].

In addition, multinational corporations have become one of the most important driving forces of constant globalization and development of the world economy. By doing business around the world and across borders in diversified environments, they have spawned and emphasized concepts such as "global managers" and intercultural management [30].

\section{Conclusion}

The study presents a systematic vision of the competency model of a successful manager, with clear priorities for their training within the context of recent global challenges. As a result of the research, the following results were obtained.

Global challenges, such as the COVID-19 pandemic, the digital transformation, demographic change, and environmental challenges, have had a significant impact on societies and economic systems at all levels. They have created both difficulties and new business opportunities and have led to the acknowledgment that the competency needs of business leaders are changing, and that outdated standards for the training of managers are no longer effective.

As a result of the systematic and structural analysis of theoretical approaches to defining a manager's competencies according to international standards, it was determined that most theoretical models contain 4-12 competencies, which are often focused on ensuring the financial success of a company and team building, which are implemented through leadership, organizational skills and communication. Therefore, for a better perception and effective approach to the preparation of training programmes for future managers, competencies are grouped into managerial (organizational) competencies (necessary for the successful achievement of business goals), non-specialized supra-professional competencies - soft skills (important both in professional activities and in everyday life), and general professional competencies - hard skills (applied to a certain group of positions). The higher the professional level of the manager, the greater the role played by soft skills, and the further back general professional competencies are pushed into the background.

An analysis of (predicted) changes in basic managerial competencies in the near future in order to determine the priorities for the training of competitive managers showed that non-specialized cognitive competencies, i.e. thinking skills, creativity, innovativeness, providing effective adaptation to the turbulence of the external global environment, will come to the fore in the next 5 years. Critical thinking will become no less important because there is an urgent need for managers to make informed decisions on various aspects of company management. Complicated business processes require non-standard solutions, so creative thinking will be at the top of the key competencies of company managements. Today, many global corporations are investing in the development of the emotional intelligence of their employees, i.e. their ability to clearly understand and manage their emotions and the emotions of the interlocutor, and to build the actual communication process on this basis. Given these trends in the transition of the dominant role of cognitive skills over basic managerial skills, it is advisable to transform training programmes for future managers towards the formation of critical thinking skills, innovative technologies, self-development, creativity, emotional intelligence and leadership skills. It should be noted that general managerial competencies do not become irrelevant, they only serve as a basis for supraprofessional competencies, especially cognitive ones.

A study of "post COVID-19" global analytical reports by top international consultancies and other organizations identifying new competencies in the model of a successful manager showed that digital and intercultural competencies help to overcome and adapt to the challenges of the global economy in today's environment. The digital competencies of a manager should be explained on the basis of three dimensions: a technological dimension through which managers are able to explore and solve problems with the help of digital technology in a new way; a cognitive dimension (the ability to read, analyse, select and interpret information on the basis of relevance, reliability and suitability); and a social dimension (the ability to teach and upskill employees in digital literacy, constructively and responsibly, and the ability to be a leader-motivator and generator of change and innovation based on digital technologies). In Ukraine, there exists an understanding at government level that company managers lack such competencies. It is within this context that the Government's project "Digital Education Diia[MVF1][OK2]" was created and implemented, which aims to increase the digital literacy 
of 6 million citizens. However, the system of training future managers in public universities is far from perfect. This is due to outdated human resources, the influence of the philosophy of the classical post-soviet education system, and the lack of sufficient funding and access to modern software. However, global analytical reviews have indicated a low level of digital competence in many countries around the world, not just in Ukraine.

Cultural self-awareness is a skill that helps managers prevent cultural conflicts and understand the impact of their own cultural beliefs and values on a person, thereby taking into account the practice of management in different cultures, as well as the impact of their own managerial and life experience. Acquiring cultural self-awareness skills is enhanced by intercultural understanding because managers can learn to recognize how their culturally implicit beliefs and values govern their behaviour in the workplace and they can see how their actions affect other workers from different cultures. Therefore, cultural self-awareness is primarily a tool for personal development that helps managers adapt their thinking and become more learning-oriented through increased interest in sources of cultural diversity, starting with their own beliefs, values and understanding of how culturally driven beliefs and values shape leadership behaviour. These two groups of skills in the system of competencies of a successful leader can be attributed to the supra-professional.

Within the framework of this scientific research, an attempt has been made to present a systematic vision of the model of a successful manager, thereby taking into account the impact of the latest globalization challenges. However, there is a need for further research in terms of empirical confirmation of the impact that the established set of managerial competencies has made on the financial and psychological well-being of managers and the financial success of employers.

\section{References}

1. N. I. Daliuk, Formuvannia profesiinykh kompetentsii suchasnoho menedzhera [Formation of professional competence of a particular manager]. Visnyk Natsionalnoho universytetu vodnoho hospodarstva ta pryrodokorystuvannia. 1(57), 109-113 (2012)

2. T. O. Kozhan, Vyznachennia vydiv kompetentsii menedzhera z personal [Visiting the competence of the manager and the staff]. Sotsialno-trudovi vidnosyny: teoriia ta praktyka. 2, 98-104 (2013)

3. I. V. Kryvoviaziuk, Skladnyky formuvannia liderskykh kompetentsii suchasnoho kerivnyka pidpryiemstva [Components of forming the leading competencies of a modern business manager]. Problemy systemnoho pidkhodu v ekonomitsi. 6(68), 90-96 (2018)

4. R. Palšaitis, K. Čižiūnienè, K. Vaičiūtè, Improvement of Warehouse Operations Management by Considering Competencies of Human Resources. 10th International Scientific Conference Transbaltica 2017: Transportation Science and Technology. Procedia Engineering. 187, 604-613 (2017)

5. M. Tomastika, J. Strohmandlb, P. Cechc, Managerial competency of crisis managers. Procedia - Social and Behavioral Sciences. 174, 3964-3969 (2015)

6. S. Blackburn, L. LaBerge, C. O`Toole, J. Schneider, Digital Strategy in a Time of Crisis [online]. Available at: https://www.mckinsey.com/business-functions/mckinsey-digital/our-insights/digital-strategy-in-a-time-of-crisis (2020)

7. Laycock, L. Gundry, Case Study: Digital transformation in the post-COVID-19 world [online]. Available at: https://www.smartindustry.com/articles/2020/case-study-digital-transformation-in-the-post-covid-19-world/ (2020)

8. G. Wilson, Accenture: industrial manufacturing post COVID-19 [online]. Available at: https://www.manufacturingglobal.com/leadership/accenture-industrial-manufacturing-post-covid-19 (2020)

9. M. Javidan, D. Bowen, The "Global Mindset" of managers: What it is, why it matters, and how to develop it. Organizational Dynamics. 42(2), 145-155 (2013)

10. Z. Nyikes, Contemporary Digital Competency Review. Interdisciplinary Description of Complex Systems. 16(1), 124-131 (2018)

11. S. Zeike, K. Bradbury, L. Lindert, H. Pfaff, Digital Leadership Skills and Associations with Psychological WellBeing. International Journal of Environmental Research and Public Health. 16(14) (2019)

12. Z. Ali, I. M. Zwetsloot, N. Nada, Operational capabilities to infuse organizational innovation in SMEs. $3^{\text {rd }}$ World Conference on Technology, Innovation and Entrepreneurship (WOCTINE). Procedia Computer Science. 158, 260269 (2019)

13. S. Kuroda, I. Yamamoto, Good boss, bad boss, workers' mental health and productivity: Evidence from Japan. Japan and the World Economy. 48, 106-118 (2018)

14. J. Koponen, S. Julkunena, A.Asai, Sales communication competence in international B2B solution selling. Industrial Marketing Management. 82, 238-252 (2019) 
15. I. V. Ivanova, Profesionalizatsiia menedzhmentu [Professionalization of management]. Kyiv: Natsionalnyi torhovoekonomichnyi universytet (2006)

16. Z. Skorková, Competency models in public sector. 3rd International Conference on New Challenges in Management and Organization: Organization and Leadership, 2 May 2016, Dubai, UAE. Procedia - Social and Behavioral Sciences. 230, 226-234 (2016)

17. O. M. Arapova, V. P. Fridrif, V. A Modyrka. Kompetentnisnyi pidkhid yak chynnyk pidvyshchennia konkurentospromozhnosti pidpryiemstva [Competent approach as a contributor to the competitiveness of the company]. Ekonomika: realii chasu. 1(6), 207-2011 (2013)

18. L. M. Spencer Jr., S. M. Spencer, Competence at Work: Models for Superior Performance. New York: John Wiley \& Sons, Inc. (1993)

19. L. Bals, H. Schulze, S. Kelly, K. Stek, Purchasing and supply management (PSM) competencies: Current and future requirements. Journal of Purchasing and Supply Management. 25, 2-14 (2019)

20. A. Maria, A.Ofei, Y. Paarima, T. Barnes, Exploring the management competencies of nurse managers in the Greater Accra Region, Ghana. International Journal of Africa Nursing Sciences. 13 (2020)

21. F. J. Lara, H. Mogorrón-Guerrero, S. Ribeiro-Navarrete, Knowledge of managerial competencies: cross-cultural analysis between American and European students. Economic Research-Ekonomska Istraživanja. 33(1), 2059-2074 (2020)

22. P. F. P. Freitas, C. C. Odelius, Managerial competencies: an analysis of classification sin empirical studies. Cadernos EBAPE.BR. 16(1), 37-49 (2018)

23. K. Dziekoński, Project Managers' Competencies Model for Construction Industry in Poland. 7th International Conference on Engineering, Project, and Production Management. Procedia Engineering. 182, 174-181 (2017)

24. J. W. S. P. Do Vale, B. Nunes, de M. M. Carvalho, Project Managers' Competences: What Do Job Advertisements and the Academic Literature Say? Project Management Journal. 49(3), 82-97 (2018)

25. L. A. Toronii, V. M. Bondarenko, Udoskonalennia suchasnoi modeli kompetentsii menedzhera. Sotsialnoekonomichni problemy suchasnoho periodau Ukrainy: zbirnyk naukovykh prats. 4(126), 69-72 (2017)

26. World Economic Forum, The Future of Jobs Report 2020 [online]. Available at: http://www3.weforum.org/docs/WEF_Future_of_Jobs_2020.pdf (2020)

27. Institute for the Future, Future work skills [online]. Available at: http://www.iftf.org/-uploads/media/SR1382A_UPRI_future_work_skills_sm.pdf (2015)

28. W. Scott, Cognitive complexity and cognitive flexibility. American Sociological Association. 25, 405-414 (1962)

29. R. M. Steers, C. J. Sanchez-Runde, L. Nardon, Management Across Cultures. Challenges and Strategies. New York: Cambridge University Press (2010)

30. A. Czarnecka, M. Szymura-Tyc. The competencies of global managers in multinational corporations. In P. Urbanek (ed.) Economy Today: An Interdisciplinary Approach to Contemporary Economic Challenges. The determinants of an organization's value. Łódź: Wydawnictwo Uniwersytetu Łódzkiego, 221-235 (2016) 